\title{
Margaret McCartney: How to misspend £2.4bn
}

\author{
Margaret McCartney, general practitioner
}

Glasgow

The General Practice "Forward View" for England and the Commons health committee's report into primary care have just been published. ${ }^{12}$ They sing in unison: general practice is the great bedrock of the NHS, but it's under unprecedented strain. More demand, more complexity, and not enough funding mean that it needs innovation and transformation.

So NHS England has promised an extra $£ 2.4$ bn ( $€ 3.09$ bn; $\$ 3.48 \mathrm{bn}$ ), a $14 \%$ increase in real terms, for "supporting and growing" general practice services.

We could spend our entire gross domestic product on health and still have a long shopping list. But, fundamentally, spending money on non-evidence based interventions leads to multiple harms: it wastes time and energy and disrupts NHS structures.

The Forward View declares an intention to spend $£ 30 \mathrm{~m}$ on "releasing time to care" and acceleration towards a paper-free environment. Where's the evidence on time saving? I used to spend 4-5 minutes completing death certificates in my neatest writing. Now it takes me much longer electronically. My secretary used to type referrals; now I have to do them electronically, eating into time needed for direct patient care.

Some $£ 45 \mathrm{~m}$ is to be spent on increasing online consultations despite a lack of evidence on effectiveness and safety about Skype consultations. ${ }^{3}$ One pilot scheme found that these took about as much time as face to face consultations. ${ }^{4}$

And we will have "accredited clinical triage systems to help patients when they feel unwell." No citation. Meanwhile, case studies of app based systems claim to avoid hospital admissions by "sending a quick message to the doctor." But it can't just be presumed that this is popular with patients.

Non-evidenced assumptions abound-for example, that more appointments at the weekend will reduce weekday demand. But it's plausible that more access will drive more demand. The health committee reports that GPs deal with only one issue or symptom per consultation; the evidence finds 2.5 problems per appointment. $^{5}$

The Forward View has two elephant sized holes.
The first omission is not mentioning that change needs to be based on high quality evidence. I agree that the Care Quality Commission's burden needs to be slashed, but the rationale-a lack of cost effectiveness-must be made crystal clear. The health committee sets out the need for evidence (especially on weekend appointments), but in the Forward View change seems to occur in the misty belief that more technology and innovation will save general practice. However, technology has the capacity to increase demand while doing nothing for the quality of care.

The second omission in the Forward View is the urgent need to stop doing things that don't work. What about ditching the Health and Social Care Act, which has taken doctors away from patients to act as commissioners? What about getting rid of health checks, dementia screening, and the targets for filling out quantities of advance care plans; or questioning why we now have masses of requests to support benefits appeals? Doctors spending more time on bureaucracy, while clinical care is done by less qualified people, is not the change we need.

Competing interests: See www.bmj.com/about-bmj/freelancecontributors/margaret-mccartney.

Provenance and peer review: Commissioned; not externally peer reviewed.

1 Royal College of General Practitioners, NHS England General practice forward view. Apr 2016. www rcgp org.uk/policy/ /media/Files/Policy/General-Practice-Forward-View/ RCGP-NHS-England-General-Practice-Forward-View-2016.ashx.

2 House of Commons Health Committee. Primary care: 4th report of session 2015-16 (HC 408). 21 Apr 2016. www.publications.parliament.uk/pa/cm201516/cmselect/cmhealth/408/ 40802.htm.

3 Greenhalgh T, Vijayaraghavan S, Wherton J, et al. Virtual online consultations: advantages and limitations (VOCAL) study. BMJ Open 2016;6:e009388. doi:10.1136/bmjopen-2015009388 pmid:26826147.

4 Central London Clinical Commissioning Group. Implementing Skype consultations in general practice: update report on the Cavendish Health Centre remote consultation service pilot project. Dec 2014. www.centrallondonccg.nhs.uk/media/24178/CLCCGCavendish-Skype-pilot-interim-report.pdf.

5 Salisbury C, Procter S, Stewart K, et al. The content of general practice consultations: cross-sectional study based on video recordings. Br J Gen Pract 2013;63:e751-9. doi:10. 3399/bjgp13X674431 pmid:24267858.

Published by the BMJ Publishing Group Limited. For permission to use (where not already granted under a licence) please go to http://group.bmj.com/group/rights-licensing/ permissions 